\section{Mediscope}

The Journal of GMC

\title{
Screening for cervical cancer in younger women may be an issue - A comparative study
}

\author{
*E Saha1, F Begum², AJ Peea ${ }^{3}$, D Saha4, D Halder ${ }^{5}$
}

\begin{abstract}
Cervical cancer is a burning issue in our health sector. A project on cervical \& breast cancer screening has been running already in Bangladesh. All sexually active women of 30-years and above or those who are married for 10 years or more are included in this project. But significant numbers of women, less than 30 years of age were referred to Colposcopy clinic for evaluation. They also had high grade lesion. The purpose of this study was to identify the need for cervical cancer screening programme in younger women who are less than 30 years old. This is a comparative retrospective study conducted in 30 years old women and less than 30 years old (21-29 years) women, who were attending Colposcopy clinic for evaluation \& treatment in Khulna Medical College \& Hospital (KMCH) from January 2013 to December 2013. We analysed 235 Colposcopies in 225 women (30 years old in Group-A; less than 30 years old in Group-B) who were attending at Colposcopy clinic in Khulna Medical College Hospital in 2013. Among group A ( $n=90)$, colposcopic findings were: normal-36 (40\%), CIN I-30 (33.33\%), CIN II-15 (16.67\%), CIN III-2 (2.22\%), invasive carcinoma-3 (3.33\%). Among group B $(n=135)$, colposcopic findings were: normal-52 (38.52\%), CIN I-38 (28.14\%), CIN II-26 (19.25\%), CIN III-3 (2.22\%), invasive carcinoma-2 $(1.48 \%)$. There characteristics were analysed and compared with each other. Although cervical cancer is extremely rare at younger age, there is increasing rate of younger women with high grade cervical lesion who may need treatment. It seems that these lesions have comparable behaviors as in older women. Early age of marriage is responsible for developing cervical cancer \& precancerous conditions. So screening should be started in earlier. Careful colposcopic assessment and evaluation before treatment remain indispensable in this regard.
\end{abstract}

1. Dr. Eti Saha, Associate Professor, Department of Gynaecology \& Obstetrics, Khulna Medical College \& Hospital, Khulna. Email: dr.etisaha@gmail.com

2. Dr. Fouzia Begum, Associate Professor, Department of Gynaecology \& Obstetrics, Khulna City Medical College, Khulna.

3. Dr. Amina Jannat Peea, Associate Professor \& Head, Department of Gynaecology \& Obstetrics, Gazi Medical College \& Hospital, Khulna.

4. Dr. Dipanwita Saha, Assistant Professor, Department of Paediatrics, (OSD-attached to BSMMU).

5. Dr. Dolly Halder, Resident Surgeon, Department of Gynaecology \& Obstetrics, Khulna medical College \& Hospital, Khulna. 
Introduction

Cervical cancer is a burning issue in our health sector. It is the most common female cancer in our country and second most common in Asia-Pacific region. About 12,931 women were suffering from cervical cancer annually in Bangladesh and about 6,561 women died due to cervical cancer in every year. $^{1}$

Cervical cancer is a preventable disease. It can be prevented in early stage of development. This is one of the few cancers that can be preventable, because abnormal cell changes can be picked up before they have changes to develop into a cancer. Cervical Intra-epithelial neoplasia (CIN) or cervical dysplasia refers to abnormal changes in the cells on the surface of the cervix. CIN II, CIN III \& invasive carcinoma comprise high grade lesions. Normal cervical epithelium changes to CIN I, then CIN II, then CIN III, and then invasive cancer. CIN is most commonly detected in women in their 20 s but can develop at any age. The peak incidence of carcinoma in situ is in women ages 25 to 35 years whereas incidence of cervical cancer rises most significantly after the age of 40 years. ${ }^{2}$ Most of the case of having $\mathrm{CIN}$ is caused by a sexually transmitted disease called HPV or Human Papilloma Virus. Cervical screening is very important because we can stop cervical cancer from developing in the first step (CIN). There are some screening tests - Pap's smear, VIA test, Colposcopy, HPV testing. Our national project on cervical and breast cancer screening has been already running. In our project, we target all sexually active women aged 30 years or more and who are married for 10 years or more for screening with VIA test in every three years. Those who are VIA positive (+ve) or suspicious, are then referred to Colposcopy clinic. Few numbers of women aged less than 30 years are referred to Colposcopy clinic for evaluation. They also have high grade lesions and need treatment. The purpose of this study was to indentify the need of cervical cancer screening among younger women who are aged 30 years and less.

\section{Materials and methods}

This is a comparative retrospective study in between 30 years old women (group -A) and less than 30 years old (21-29years) (group -B), who were attending colposcopy clinic for evaluation and treatment of cervical lesions in $\mathrm{KMCH}$ from January 2013 to December 2013. Women more than 30 years old who attended Colposcopy clinic were excluded from this study. Criteria to attend colposcopy clinic are positive VIA test done by FWV, nurses, doctors in different centre in Khulna division; Suspicious cervix; history of postcoital bleeding; abnormal cells on Pap's smear and post menopausal bleeding. P-value was determined by Fisher's exact probability test (one tailed probability).

\section{Results}

Total 616 women came in Colposcopy clinic KMCH from January 2013 to December 2013 for evaluation and treatment of cervical lesions. Among them, numbers of women at the age of 30 years and below were 225. We analysed 235 colposcopic examinations in 225 women. Among 225 women, 90 (40\%) were at the age of 30 years (group-A) and $135(60 \%)$ were less than 30 years old (21-29 years) (group-B). 
Table 01: Educational status, Duration of married life, Parity, Socio- Economic status among groups

\begin{tabular}{|l|l|l|l|}
\hline & & Group-A (n=90) & Group-B (n=135) \\
\hline Educational status & No Education & $20(22.22 \%)$ & $15(11.11 \%)$ \\
\cline { 2 - 4 } & Primary level & $33(36.67 \%)$ & $48(35.36 \%)$ \\
\cline { 2 - 4 } & More than primary level & $37(41.11 \%)$ & $72(53.33 \%)$ \\
\hline \multirow{4}{*}{$\begin{array}{l}\text { Duration of married } \\
\text { life }\end{array}$} & $<5$ years & 0 & $12(8.89 \%)$ \\
\cline { 2 - 4 } & $5-9$ years & $3(3.33 \%)$ & $52(38.51 \%)$ \\
\cline { 2 - 4 } & 10 years or more & $87(96.67 \%)$ & $71(52.6 \%)$ \\
\hline Parity & Para-0 & 0 & $6(4.44 \%)$ \\
\cline { 2 - 4 } & Para-1 & $15(16.67 \%)$ & $53(39.25 \%)$ \\
\cline { 2 - 4 } & Para-2 & $55(61.11 \%)$ & $66(48.89 \%)$ \\
\cline { 2 - 4 } & Para-3 or more & $20(22.22 \%)$ & $10(7.40 \%)$ \\
\hline \multirow{3}{*}{$\begin{array}{l}\text { Socio- Economic } \\
\text { status among } \\
\text { groups (monthly } \\
\text { income) }\end{array}$} & $\square 5000 /=$ & $50(55.55 \%)$ & $75(55.55 \%)$ \\
\cline { 2 - 4 } & $5000-10,000 /=$ & $25(27.78 \%)$ & $42(31.11 \%)$ \\
\cline { 2 - 4 } & $10,000-20,000 /=$ & $12(13.33 \%)$ & $13(9.63 \%)$ \\
\cline { 2 - 4 } & $>20,000 /=$ & $3(3.33 \%)$ & $5(3.70 \%)$ \\
\hline
\end{tabular}

Table 01 shows educational status, Duration of married life, parity and socio-economic status of both groups. No remarkable difference is present in both groups regarding education level and socio-economic status. Duration of married life were equal or more than ten years in 87 participants $(96.67 \%)$ in group-A and 71 participants (52.6\%) in group-B. In group-A, parity was more than two in 55 cases $(61.11 \%)$ \& more than three in 20 cases $(22.22 \%)$; whereas in group-B, it was $66(48.89 \%) \& 10(7.40 \%)$ respectively.

Table 02: Prevalence of precancerous lesions among groups $(n=225)$

\begin{tabular}{|l|l|l|l|}
\hline \multicolumn{1}{|c|}{ Colposcopic findings } & \multicolumn{1}{|c|}{ Group-A (n=90) } & \multicolumn{1}{c|}{ Group-B (n=135) } & \multicolumn{1}{c|}{ P-value } \\
\hline Normal & $36(40 \%)$ & $52(38.52 \%)$ & 0.49 \\
\hline CIN I & $30(33.33 \%)$ & $38(28.14 \%)$ & 0.32 \\
\hline CIN II & $15(16.67 \%)$ & $26(19.25 \%)$ & 0.40 \\
\hline CIN III & $2(2.22 \%)$ & $3(2.22 \%)$ & 0.68 \\
\hline Invasive Cancer & $3(3.33 \%)$ & $2(1.48 \%)$ & 0.32 \\
\hline $\begin{array}{l}\text { Cervical ectropion or chronic } \\
\text { cervicitis, warts }\end{array}$ & $4(4.44 \%)$ & $14(10.37 \%)$ & 0.10 \\
\hline
\end{tabular}

Table 02 shows prevalence of precancerous lesions among groups. In group-A, colposcopic findings were: normal-36(40\%), CIN I-30 (33.33\%), CIN II-15 (16.67\%), CIN III-2 (2.22\%), invasive carcinoma-3(3.33\%). In group-B, colposcopic findings were: normal-52 (38.52\%), CIN I-38 (28.52\%), CIN II-26 (19.25\%), CIN III-3(2.22\%) and invasive carcinoma-2 (1.48\%). In group-A, $47(52.22 \%)$ women had precancerous lesion \& in group-B, 67(49.63\%) had that lesion. 
Table 03: Correlation between age of marriage and CIN (precancerous lesion), Ca cervix.

\begin{tabular}{|c|c|c|c|c|c|}
\hline \multirow[b]{2}{*}{$\begin{array}{l}\text { Colposcopy } \\
\text { findings }\end{array}$} & \multirow[b]{2}{*}{ Group } & \multicolumn{4}{|c|}{ Age of marriage ( $n=225)$} \\
\hline & & $\begin{array}{c}10-15 \text { years } \\
(n=127) \\
56.44 \%\end{array}$ & $\begin{array}{c}16-18 \\
\text { years }(n=80) \\
35.56 \%\end{array}$ & $\begin{array}{c}19-20 \text { years } \\
(n=15) \\
6.67 \%\end{array}$ & $\begin{array}{c}\text { More than } 20 \\
\text { years } \\
(n=3) 1.33 \%\end{array}$ \\
\hline \multirow[t]{2}{*}{ Normal } & $\begin{array}{l}\text { Group-A } \\
(n=90)\end{array}$ & $24(26.66 \%)$ & $12(13.33 \%)$ & $2(2.22 \%)$ & $2(2.22 \%)$ \\
\hline & $\begin{array}{l}\text { Group-B } \\
(n=135)\end{array}$ & $36(26.67 \%)$ & $22(16.3 \%)$ & $8(5.93 \%)$ & 0 \\
\hline \multirow[t]{2}{*}{ CIN I } & $\begin{array}{l}\text { Group-A } \\
(n=90)\end{array}$ & $16(17.77 \%)$ & $12(13.33 \%)$ & $2(2.22 \%)$ & 0 \\
\hline & $\begin{array}{l}\text { Group- B } \\
(n=135)\end{array}$ & $24(17.78 \%)$ & $13(9.62 \%)$ & $1(0.74 \%)$ & 0 \\
\hline \multirow[t]{2}{*}{ CIN II } & $\begin{array}{l}\text { Group- A } \\
(n=90)\end{array}$ & $5(5.55 \%)$ & $8(8.88 \%)$ & $1(1.11 \%)$ & $1(1.11 \%)$ \\
\hline & $\begin{array}{l}\text { Group-B } \\
(n=135)\end{array}$ & $14(10.37 \%)$ & $11(8.15 \%)$ & $1(0.74 \%)$ & 0 \\
\hline \multirow[t]{2}{*}{ CIN III } & $\begin{array}{l}\text { Group-A } \\
(n=90)\end{array}$ & 0 & $2(2.22 \%)$ & 0 & 0 \\
\hline & $\begin{array}{l}\text { Group-B } \\
(n=135)\end{array}$ & $3(2.22 \%)$ & 0 & 0 & 0 \\
\hline \multirow[t]{2}{*}{ Ca cervix } & $\begin{array}{l}\text { Group-A } \\
(\mathrm{n}=90)\end{array}$ & $3(3.33 \%)$ & 0 & 0 & 0 \\
\hline & $\begin{array}{l}\text { Group-B } \\
(n=135)\end{array}$ & $2(1.48 \%)$ & 0 & 0 & 0 \\
\hline
\end{tabular}

Table 03 shows correlation between the age of marriage and CIN I, CIN II, CIN III, ca cervix. CIN I lesion were seen in 16 women in group-A who were married before 16 years, whereas 12 women had lesions who started their sexual life in 16 to $18 y e a r s, 2$ ladies who started at the age of 18 to 20 years \& no lesion found who married after 20 years. In group-B CIN I lesion were seen among 38 women- 24 of them were married between age 10 to 15 years, 13 women between 16 to 18 years, one woman were married at 20 years. Cancerous lesions were found in both groups who started sexual life before the age of sixteen years. CIN III was found in group-B: 3 women married between age 10-15 years and in group-A, 2 women started their sexual life between age 16 to 18 years. CIN II lesions were seen in 13 women who started their sexual life before 18 years, and in 2 women who married after 18 years in group-A. In group-B, 25 women had been suffering from CIN II who married before the age of 18 years whereas only one woman who got married at 19 years, suffered from it. 
Table 04: Types of cervical treatments received by the subjects

\begin{tabular}{|c|c|c|c|c|c|c|}
\hline $\begin{array}{l}\text { Name of } \\
\text { lesion }\end{array}$ & Group & $\begin{array}{c}\text { No } \\
\text { treatment } \\
\text { (only } \\
\text { follow up) }\end{array}$ & $\begin{array}{c}\text { Electro- } \\
\text { coagulation }\end{array}$ & $\begin{array}{c}\text { Cold } \\
\text { coagulation }\end{array}$ & $\begin{array}{c}\text { LEEP } \\
\text { (Loop } \\
\text { Electrosurgical } \\
\text { Excision } \\
\text { procedure ) }\end{array}$ & \begin{tabular}{|c|} 
Admission \\
for EUA \\
(Examination \\
under \\
general \\
anaesthesia)
\end{tabular} \\
\hline \multirow[t]{2}{*}{ CIN I } & $\begin{array}{l}\text { Group-A } \\
(n=30, \text { among } \\
90)\end{array}$ & $2(2.22 \%)$ & $1(1.11 \%)$ & $\begin{array}{l}21 \\
(23.33 \%)\end{array}$ & $\begin{array}{l}6 \\
(6.67 \%)\end{array}$ & 0 \\
\hline & $\begin{array}{l}\text { Group-B } \\
(n=38, \text { among } \\
135)\end{array}$ & $4(2.96 \%)$ & $3(2.22 \%)$ & $\begin{array}{l}25 \\
(18.52 \%)\end{array}$ & $\begin{array}{l}6 \\
(4.44 \%)\end{array}$ & 0 \\
\hline \multirow[t]{2}{*}{ CIN II } & $\begin{array}{l}\text { Group-A } \\
(n=15, \text { among } \\
90)\end{array}$ & 0 & 0 & $4(4.44 \%)$ & $\begin{array}{l}11 \\
(12.22 \%)\end{array}$ & 0 \\
\hline & $\begin{array}{l}\text { Group-B } \\
(n=26, \text { among } \\
135)\end{array}$ & 0 & $1(0.74 \%)$ & $5(3.70 \%)$ & $20(14.81 \%)$ & 0 \\
\hline \multirow[t]{2}{*}{ CIN III } & $\begin{array}{l}\text { Group-A } \\
(n=2)\end{array}$ & 0 & 0 & 0 & $2(2.22 \%)$ & 0 \\
\hline & $\begin{array}{l}\text { Group-B } \\
(n=3)\end{array}$ & 0 & 0 & 0 & $3(2.22 \%)$ & 0 \\
\hline \multirow{2}{*}{$\begin{array}{l}\text { Invasive } \\
\text { carcinoma }\end{array}$} & Group-A $(n=3)$ & 0 & 0 & 0 & 0 & $3(3.33 \%)$ \\
\hline & Group- B (n=2) & 0 & 0 & 0 & 0 & $2(1.48 \%)$ \\
\hline
\end{tabular}

Table 04 shows types of cervical treatments received by the study subjects. LEEP was done in 6 women both in group-A $(6.67 \%)$ and in group-B (4.44\%) who had CIN I. Number of women having CIN II who received LEEP was $11(12.22 \%$ ) in group-A and $20(14.81 \%)$ in group-B. Number of women having CIN III who received LEEP was $2(2.22 \%)$ in group-A and $3(2.22 \%)$ in group-B. Total number of women who received treatment was $48(53.33 \%)$ in group-A and 65 (48.15\%) in group-B. 
Discussion

Surprisingly, cervical cancer is preventable disease but yet not prevented. It is preventable in developing countries make $80 \%$ of global burdens. Patients have been suffering from this disease in Bangladesh, Nepal, India and Sri Lanka in about one-third of global sufferers. Preventable measures are neither uniformly nor vigorously implemented. In 2012 new and generally consistent cervical cancer screening recommendations for the general population, HPV vaccinated and unvaccinated, were released by two separate group: the U.S preventive services Task force (USPSTF) and the multi disciplinary partnership of the American cancer society, American society for Colposcopy and cervical pathology, and American society of clinical pathology (ACS/ASCCP/ASCP). ${ }^{2}$ Cervical cytology screening should not begin before age 21 regardless of the age at onset of sexual intercourse. It is recommended every 3 years for women 21-29 years of age, women age 30 or older should be screened with cytology and HPV co-testing every 5 years on cytology alone every 3 years. $^{2}$

In England, Wales and Northern Iceland, women between the ages of 25 and 64 are screened. In Belgium, there was no national organized cervical screening program although it is advised to screen the primary target populations between 25 and 65 years, cervical cancer are often present to younger women. ${ }^{3}$ Cervical cancer incidence by age 0-19 about 0.1\% 1,00,000, age 20-29 about $4.5 / 1,00,000$, whereas age 30-39 about $13.9 / 1,00,000$, age $40-49$ about $16.5 / 1,00,000$. So below 30 years age group cervical cancer is not rare. ${ }^{4}$ In that study showed that 116 numbers of women among 1387 numbers of women are less than 25years who received cervical treatment for low grade CIN and 66 women receive treatment for high grade CIN. ${ }^{4} \mathrm{HPV}$ infection is more prevalence in Manchester, UK below 25 years of age group population than above 25 years. ${ }^{5}$ One study among US where showed HPV infection is high risk below 25 years age group. 6

In our study low grade lesions is comparable in both group, CIN I were about 30 (33.33\%) in group-A, whereas $38(28.52 \%)$ in group-B ladies ( $p$-value 0.32). High grade lesions had in group-A about $20(22.22 \%)$ ladies and in group-B about 31 (22.96\%) ladies, near about same in both groups. Total treatment were received in group-A $48(53.33 \%)$, whereas in group-B 65 (48.15\%) ladies. In this study, CIN III or high grade lesions found in ladies who were only 23 years old, 27 years old, 29 years old. Invasive carcinoma found in 22 years old lady who was married for 7 years and another lady who was 28 years old, married for 15 years.

In this study, early age of marriage is a factor for developing CIN \& cancer cervix. 43 $(31.85 \%)$ ladies who started their marital life before sixteen years had lesions in group $B$ \& $24(26.67 \%)$ ladies of group-A, whereas no one had lesion in group-B who married after 20 years \& only 3 ladies of group-A. There is an existing law in Bangladesh that age of marriage of a girl must be above sixteen. But due to poverty, low social security this law was violated repeatedly. That is why, younger ladies are more prone to develop cervical cancer. So earlier screening for cancer cervix is essential.

A large amount of ladies age below 30 years old are not screened for cervical cancer in national program, but they have high grade lesions and need treatments. Precancerous lesions of cervix usually have no symptoms, unless it is invasive. So screening is the best option for prevention. Precancerous high grade lesions may develop in early age (less than 30 years). If we diagnosis early and treat then it will not become invasive carcinoma. 
Screening program should be started at the early age, at least from the age of 25 years.

\section{Conclusion}

Although cervical cancer is extremely rare at younger age, there is increasing rate of young women with high grade cervical lesion who may need treatment. It seems that these lesions have comparable behaviors as in older women. In this study, cervical cancer and precancerous condition is found more in who started their sexual life (married) before sixteen years. So starting age of screening should be earlier. The questions arise if these are equally significant precancerous lesions and whether we should start screening and consequently treating at an earlier age considering the associated morbidity. Careful colposcopic assessment and following evaluation before treatment remain indispensable.

\section{References}

1. Ferlay J, Bray F, Pisani P, Parkin DM (2004).GLOBOCON 2002: Cancer incidence, Mortality and prevalence Worldwide. IARC Cancer base no. 5, version 2.0, IARC Press, Lyon.

2. Christine H. Holschineider, MD. Premalignant \& malignant disorders of the uterine cervix, Current Diagnosis \& Treatment
Obstetrics \& Gynecology, eleventh edition, Lange, united States of America, The McGraw- Hill companies, 2013, page 807-809.

3. Philippe de Sutter. Characteristics of CIN treatment in young women study in university hospital, Brussels, Belgium, 16th World congress on controversies in Obstetrics, Gynaecology and infertility, Singapore,19 - 22 July ,2012.

4. Saraiya M; Ahmed F; Krishnan S; Richards TB; Unger ER; Lawson HW Cervical cancer incidence in a prevaccine era in the United States, 1998-2002.Obstet Gynecol. 2007; 109: 360-70.

5. Peto J, Gilham C, Deacon J, Taylor C, Evans C, Binns W, Haywood M, Elanko N, Coleman D, Yule R, Desai M. Cervical HPV infection and neoplasia in a large population-based prospective study: the Manchester cohort. Br J Cancer. 2004 Aug 31; 91(5):942-53.

6. Hariri S, Unger ER, Sternberg M, Dunne EF, Swan D, Patel S, Markowitz LE. Prevalence of genital human Papilloma virus among females in the United States, the National Health and Nutrition Examination Survey, 2003-2006. J Infect Dis. 2011 Aug 15; 204(4):566-73 